do naukowego poznania zawartego w jej tytule fenomenu. Jest jedynie przyczynkiem do dyskusji, której głównymi uczestnikami wydają się być badacze, których Autorka nawet nie zna, pomijając zupełnie ich publikacje. Wspomnieć można w związku z tym o takich autorach jak Fawaz A. Gerges, Farhad Khosrokhavar, Jalil Roshandel, Sharon Chadha, Brynjar Lia czy Jarret Brachman. Wysoki poziom edytorski pracy i zrozumiała dla przeciętnego czytelnika narracja nie stanowią wystarczających argumentów, które upoważniałyby do jej rekomendowania szerokiemu gronu adresatów.

Artur WEJKSZNER

Uniwersytet im. Adama Mickiewicza, Poznań

\title{
Radosław Fiedler, Od przywództwa do hegemonii. Stany Zjednoczone wobec bliskowschodniego obszaru niestabilności w latach 1991-2009, Wydawnictwo Naukowe WNPiD UAM, Poznań 2010, ss. 416.
}

Od zakończenia II wojny światowej region Bliskiego Wschodu stanowi przedmiot zainteresowania społeczności międzynarodowej, ze szczególnym uwzględnieniem światowych mocarstw. Fascynacja wszystkim co bliskowschodnie przekłada się na mnogość publikacji. Samych monografii są tysiące. Również w Polsce ukazuje się co roku kilkadziesiąt nowych publikacji dotyczących historii, stosunków politycznych, społeczeństwa lub kwestii ekonomicznych na Bliskim Wschodzie. Co więcej, wiele spośród nich dotyka rozmaitych zagadnień związanych z potencjalnymi zagrożeniami oraz konfliktami w regionie. Tym samym wyraźnie wzrasta poziom trudności, przed którym staje każdy kolejny autor, mający ambicję napisania książki unikalnej, a poświęconej tematyce bliskowschodniej.

Z pewnością najnowsza książka autorstwa Radosława Fiedlera nie jest tylko kolejna, jedną z wielu książką dotyczącą sytuacji politycznej na Bliskim Wschodzie. Obszerna, wyczerpująca monografia jest publikacją unikalną na polskim rynku wydawniczym. Dotychczas w języku polskim ukazało się kilkanaście książek, w których analizie poddano zaangażowanie polityczne Stanów Zjednoczonych w regionie. Niemniej należy wyraźnie podkreślić, iż były to analizy fragmentaryczne, podczas gdy Radosław Fiedler przygotowal rzetelna, całościową analizę polityki USA wobec bliskowschodniego obszaru niestabilności ${ }^{1}$.

1 Wśród wspomnianych publikacji należy wymienić, między innymi, następujące pozycje: R. Bania, Polityka Stanów Zjednoczonych wobec Bliskiego Wschodu za prezydentury Dwighta D. Eisenhowera, Wydawnictwo Adam Marszałek, Toruń 2000; T. Brańka, M. Lorenc, P. Osiewicz, A. Potyrała, Irak między wojna a pokojem, Wydawnictwo MADO, Torun 2010; Irak. Dylematy amerykańskiej interwencji, red. W. Dzielski, W. Michnik, Księgarnia Akademicka, Kraków 2007; T. A. Kisielewski, Wojna Imperium. Większy Bliski Wschód w amerykańskiej wojnie z terroryzmem, Wydawnictwo Sprawy Polityczne, Elbląg 2008; A. Lukaszewicz, Afganistan i Irak: ekonomiczny bilans wojny z terroryzmem, Instytut Stosunków Międzynarodowych UW, Warszawa 2010; B. Wróblewski, Polityka Stanów Zjednoczonych wobec sojuszu egipsko-radzieckiego w latach 1971-1976, Wydawnictwo Adam Marszałek, Torun 2002; J. Zając, Srodki i metody oddzialywania USA w bliskowschodnim procesie pokojowym (1991-2000), Wydawnictwo Uniwersytetu Warszawskiego, Warszawa 2005. 
Książka zatytułowana Od przywództwa do hegemonii. Stany Zjednoczone wobec bliskowschodniego obszaru niestabilności w latach 1991-2009 została podzielona na sześć rozdziałów tematycznych. Jednocześnie zachowany został porządek chronologiczny, który nie tylko ułatwia lekturę całej pracy, ale także pozwala innym badaczom na wykorzystanie jej części podczas opracowywania poszczególnych zagadnień.

Wybór tytułowego określenia „,bliskowschodni obszar niestabilności” wydaje się słuszny z co najmniej kilku powodów. Po pierwsze, wciąż nieuregulowany pozostaje konflikt izraelsko-palestyński. Po drugie, Islamska Republika Iranu wciąż kontynuuje prace badawcze w ramach narodowego programu atomowego, co wciąż wiąże się z ryzykiem ataku ze strony zaniepokojonego tym faktem Izraela. Po trzecie, arabska wiosna z 2011 roku (Egipt, Bahrajn, Jemen) oraz trwające wciąż walki w Syrii dowodzą, iż duża dynamika zmian politycznych oraz będąca jej konsekwencją nieprzewidywalność pozostają cechami wyróżniającymi Bliski Wschód na tle pozostałych regionów na świecie. Po czwarte, coraz wyraźniejsza rywalizacja między światowymi mocarstwami w regionie (Stany Zjednoczone, Federacja Rosyjska, Chińska Republika Ludowa, Unia Europejska), zwłaszcza w kontekście rywalizacji o dostęp do surowców (ropa naftowa, gaz ziemny). Po piąte, coraz wyraźniejszy staje się rozdźwięk w stosunkach amerykańsko-tureckich, a sama Turcja z powodzeniem realizuje ,neoosmańską” koncepcję polityki zagranicznej Ahmeta Davutoğlu.

W monografii wiele miejsca zajęło przedstawienie oraz pogłębiona ocena uwarunkowań wewnętrznych i zewnętrznych bliskowschodniego obszaru niestabilności. W tym kontekście Radosław Fiedler skoncentrował się przede wszystkim na kwestiach surowcowych i ich wpływie na zainteresowanie sytuacją w regionie ze strony zewnętrznych aktorów, w tym przede wszystkim Stanów Zjednoczonych. Wystarczy wspomnieć o amerykańskiej, politycznej dominacji w regionie od czasów wprowadzenia doktryny Eisenhowera.

Autor wiele uwagi poświęcił także analizie podstaw polityki zagranicznej Stanów Zjednoczonych wobec Bliskiego Wschodu po zakończeniu zimnej wojny, co zostało także podkreślone w przyjętych w tytule ramach czasowych monografii (1991-2009). Na szczególną uwagę zasługuje ciekawa ocena neokonserwatywnej wizji hegemonii USA (s. 61-83) oraz umacniania amerykańskiego, politycznego przywództwa na Bliskim Wschodzie od doktryny Trumana do Pustynnej Burzy (s. 119-160). Ponadto, w publikacji znalazlo się miejsce na ocenę polityki USA w regionie w okresie prezydentury George'a W. Busha, zwłaszcza w kontekście wojny w Iraku.

Radosław Fiedler zwrócił uwagę na rolę stosunków bilateralnych, a w szczególności stan stosunków amerykańsko-irańskich, amerykańsko-tureckich oraz amerykańsko-izraelskich. Analizie poddane zostały także związki łączące Stany Zjednoczone z poszczególnymi arabskimi państwami w rejonie Zatoki Perskiej. Uzupełnienia wymagałby jedynie fragment dotyczący polityki USA wobec Syrii (s. 184-186). Zabrakło osobnego podrozdziału poświęconego aktywności amerykańskiej w Libanie czy też zaangażowania i obecności w Jordanii. Pominięty został także Jemen, który, co świadczy na korzyść Autora, nabrał szczególnego znaczenia w polityce USA dopiero podczas arabskiej wiosny w 2011 roku, a zatem już po opublikowaniu niniejszej książki. Pomimo wszystko można jednak zaryzykować stwierdzenie, że wyżej wymienione braki i tak nie mają wpływu na wnioski końcowe, które Radosław Fiedler sformułował wręcz wzorcowo. Zwłaszcza relacje amerykańsko-jordańskie nie wpisują się w przyjęty przez Autora schemat analizy regionu Bliskiego Wschodu jako obszaru niestabilności. 
W książce znaleźć można bardzo wiele przypisów opisowych, które uzupełniają główny wywód Autora i świadczą o jego erudycji. W niektórych przypadkach przypisy zajmują prawie cała stronę (na przykład, s. 188-189), co przy małej czcionce znacznie utrudnia lekturę. Niemniej, zarówno imponująca liczba, jak i jakość wykorzystanych materiałów źródłowych, zasługują na najwyższe uznanie. Wystarczy wspomnieć, że w toku prac nad książką Radosław Fiedler skorzystał z setek dokumentów, monografii oraz artykulów. Większość z nich stanowią publikacje w języku angielskim, co wiązało się z koniecznością thumaczeń i interpretacji materiałów. Bibliografia obejmuje aż 39 stron. Całość uzupełniają 42 tabele, osiem schematów oraz aneks, zawierający pięć map.

Podsumowując, z całą pewnością najnowsza publikacja autorstwa Radosława Fiedlera jest pozycją wartą polecenia wszystkim zainteresowanym nie tylko sytuacją polityczną na Bliskim Wschodzie czy też polityką zagraniczną Stanów Zjednoczonych, ale też wszystkim czytelnikom, którym bliskie są współczesne stosunki międzynarodowe. Książka stanowi cenny wkład w rozwój polskiej literatury przedmiotu oraz jest przykładem, świeżego spojrzenia" na bieżące wydarzenia w regionie. W przeciwieństwie do książek wielu autorów amerykańskich, monografia Radosława Fiedlera nie zdradza zaangażowania po którejś ze stron amerykańskiej sceny politycznej i stanowi udaną próbę bezstronnej oceny polityki zagranicznej USA w odniesieniu do Bliskiego Wschodu. Jej mocnymi stronami sa przede wszystkim rzetelne opracowanie, solidna podstawa źródłowa, oryginalność spostrzeżeń oraz aktualność.

Przemysław OSIEWICZ Uniwersytet im. Adama Mickiewicza, Poznań

\section{Joanna Dobrowolska-Polak, Ludzie w cieniu wojny. Ludność cywilna podczas wspótczesnych konfliktów zbrojnych, Poznań 2011, ss. 224}

Monografia Ludzie w cieniu wojny podejmuje temat rzadko rozpatrywany w polskiej literaturze naukowej-sytuację ludności cywilnej na obszarach konfliktów zbrojnych. Analizuje ona także normy prawa międzynarodowego określające należny sposób traktowania ludności cywilnej oraz ocenia stopień ich implementacji.

Ludność cywilna stanowi obecnie około 90 procent wszystkich śmiertelnych ofiar wojen czy konfliktów zbrojnych. Ze względu na charakter współczesnych konfliktów odsetek cywilów wśród ogółu ofiar cały czas wzrasta. Dla przykładu podczas pierwszej wojny światowej wynosil on 5, a w trakcie drugiej wojny światowej już 50 procent. Stąd też konieczność dokonania analizy nie tylko współczesnych wojen czy konfliktów, ale także ukazania zakresu ochrony przysługującej ludności cywilnej. Bezpośrednio i pośrednio nawiąuje do tego pierwsza część książki. Został w niej przedstawiony również proces ,humanitaryzacji wojny", który doprowadził do powstania koncepcji ,,minimalnego standardu humanitarnego" czy też - przyjmując terminologię ONZ - ,fundamentalnego standardu ludzkości", określającego katalog norm obowiązujących w każdej sytuacji, niezależnie od charakteru i rodzaju konfliktu zbrojnego. Autorka szczególowo omawia też następujące kwestie: zasady prawa wojennego, rozwój praw człowieka i prawa humanitarnego, ochronę m.in. dzieci, 